\title{
Intellectual property as instrument for implementation of innovative technologies
}

\author{
Nikitenko Sergey Mihailovich \\ Department of Economics \\ Plekhanov Russian University of Economics \\ Kemerovo, Russian Federation \\ nsm.nis@mail.ru
}

\author{
Mesyats Maria Anatolievna \\ Department of Economics \\ Plekhanov Russian University of Economics \\ Kemerovo, Russian Federation
}

\author{
Pakhomova Evgenia Olegovna \\ Laboratory of monitoring and forecasting development \\ PPP projects in the field of integrated development of mineral resources \\ Federal Research Center of Coal and Coal Chemistry, \\ SB of RAS \\ Kemerovo, Russian Federation
}

\begin{abstract}
This article is devoted to the study of features related to the pledge of intellectual property in foreign and domestic practice. Carrying out pledge transactions on objects of intellectual property accelerates the pace of creating innovative systems in the economy. In present paper, the modern scheme for bank loan and financing, secured with patented intellectual property, is researched. The authors give the brief description of features of pledge security registration for loans in some Europe countries. The Europe Union experience shows that trademarks, patents for intellectual property objects, as well as applications for their registration can be used as collateral for obtaining monetary loans. Russian experience of the pledge operations of the intellectual property is too small. This version of bank lending is at the initial stage of development. The main constraint is the difficulty of assessing the value of the pledged intellectual property as intangible assets. However, taking into account the world and domestic practice, IP pledge operations are estimated by the authors as a promising trend for the Russian market. This article was prepared with the financial support of the Russian scientific Foundation, project № 17-78-20218.
\end{abstract}

Keywords- bail, cooperation, developing regions, interaction, intellectual property

\section{INTRODUCTION}

The main challenge for the world's economies today is the process of building national and regional innovation systems. The methodological basis for this is the Triple Helix Model, describing the directions and forms of cooperation among science, businesses and government in the innovation sphere, and its «evolution» sequel - the Quadruple-Helix Model, which includes the civil society along with the three listed participants.

Since then, the conditions have changed. New organizational and economic diffusion (transfer) tools of intellectual activity as the basis for innovative development have appeared. Today, technology transfer takes into account the «host regions», their resource security, economic, environmental and social component. The synergistic effect plays an important role due to innovative technologies complementarity.

Practice has shown that harmonization on the basis of pledge mechanisms of intellectual property management processes can significantly speed up the innovation implementation process and help to equalize the socioeconomic development levels of individual subjects and their economy promotion in an innovative way. This is a new phenomenon in Russia. Therefore, the experience of European countries in the intellectual property management, including intellectual property rights as a pledged asset, is so important for Russia.

In recent years, an institutional leap towards the formation of institutions of investment in intellectual property (IP) has been taken in Russia. As a result, in 2016, about 20 leading Russian banks concluded 81 pledge agreements over the exclusive rights to trademarks, inventions, utility models and industrial designs. The role of regional funds to support small and medium-sized innovative companies, providing on behalf of the government pledges to commercial banks, has been growing.

According to the Encyclopedia of a Lawyer, intellectual property (IP) is an exclusive right of a citizen or a legal entity to the results of intellectual activity and the means of individualization of a legal entity, products, works or services that are equal to them (company name, trademark or service mark). The main purpose of commercial use of intellectual property objects (IPOs) is to generate profit. The objects of transactions are not the objects themselves, but the property rights to these objects, including patents and patent 
applications. They are the assets that are used as pledge for loans or other loan agreements. Formal (patents and trademarks that are objects of the official registration system) and informal (copyright) intellectual property rights are considered to be intellectual property rights for the purposes of IP lending. Formal intellectual property rights protect the monopoly and, as a rule, they do not exist for as long as some informal intellectual property rights. In the case of registered trademarks, the rights may be used for an indefinite period, provided that the rights to IP continue to be used.

At the same time, the pledge activity directly depends on another indicator of the development of innovative technologies. That is patent activity.

The World Intellectual Property Organization in recent years has recorded a steady increase in the number of patent applications. Most of them come from only eight countries, of which Russia is not a member [1,2]. The Russian Federation ranks 11th in the world by the number of applications for patenting inventions, taking into account the applications of residents and foreign applicants; 7 th - by the number of applications for inventions submitted by residents; 16 th - by the number of filed patent applications for 100 billion dollars of gross domestic product (GDP); and 19th - by the number of filed patent applications per capita.

According to some researchers, Russia's position on the already developed and emerging world markets of high-tech products is more characterized by the patent portfolio of Russian residents, formed in foreign patent offices and, first of all, patent families in certain areas of technology. In the course of the study, the authors found that in Russia neither the Federal Institute of Industrial Property (FIPS) nor the Federal Service for Intellectual Property (Rospatent) nor numerous analytical centers provide publicly available annual reviews, containing a detailed analysis of the national patent flow, generated in the past year or in a short-term retrospective.

Meanwhile, the analysis of current patent information allows monitoring trends in markets created by high-tech goods and services, determine the feasibility of exporting industrial products, search for industrial partners, etc. The authors of this publication also emphasize the importance and necessity of patent analysis as an important component of scientific and technological policy, including the formation of new organizational and financial instruments for managing intellectual property with a view to its commercialization.

\section{MethodS}

The conducted research uses general scientific methods of systematization and analysis of the IP rights pledge practice in foreign countries, allowing the assessment of the possibilities of this experience usage in Russia.

\section{RESULTS AND DISCUSSION}

The main purpose of commercial use of intellectual property objects is to generate profit. The objects of transactions are not the objects themselves, but the property rights to these objects, including patents and patent applications. They are the assets that are used as pledge for loans or other loan agreements [3].

Such assets are especially valuable for businesses engaged in research and results commercializing. In this situation, the patent portfolio at a cost can many times exceed the value of other assets of the company and act as the most valuable asset.To date, in developed countries, IP investment accounts for more than $15 \%$ of GDP and almost half of all investments in fixed capital. The share of IP investment made by the largest international corporations is rapidly growing [4]. So, if in the early $80 \mathrm{~s}$ of the 20 th century, the share of intangible assets in the structure of the cost of American companies accounted for no more than $40 \%$, then at the beginning of the 21 st century their share exceeded $70 \%$. At the same time, 30$40 \%$ of non-material property was not identified and reflected in corporate balances. This allows saying that the share of intangible assets can actually be even higher. A similar picture is typical for West European corporations [5]. According to Interbrand consulting company, tangible and intangible assets of the world well-known companies are correlated as follows: British Petroleum - 30:70, IBM - 17: 83, Coca-Cola - 4:96. For comparison, in Russia, the volume of investment in intellectual property objects has not exceeded $1 \%$ so far [6].

It is important to note that pledge transactions, involving the use of IP's rights along with benefits, carry potential high risks for the parties involved. To reduce them, countries are developing special legislation, regulating transactions with IPO rights; companies and banks use such protection mechanisms as a preliminary assessment of IP's market value, determining the best way to calculate depreciation charges and depreciation periods, revaluing the cost, using IP as a pledge in combination with other assets of the enterprise, preliminary expert analysis of the economic efficiency of the IP use, etc.

In addition, many countries provide for the possibility of registering transactions with industrial property in the public registry, which guarantees the rights of parties involved in the transaction. The French Intellectual Property Code defines the rules regarding the pledge of the right to use the software. Article L 132-34 of this Code provides for mandatory registration of a pledge in the special register of the National Institute of Industrial Property (INPI) [7; $; 9 ; 10 ; 11]$. In Austria and the United States, the exclusive rights are not the subject of the pledge, but the patent itself as movable property. A pledge transaction must be registered with the Patent Office [12].

In the case of a pledge over formal intellectual property rights, the EU countries take into account the following points:

- public registers operate a priority system, granting to the first applicant a priority pledge right over Formal IP Rights;

- formalities for creating the pledge over the Formal IP Rights are regulated by the law of the country, in which the pledge right needs to take effect;

- the Formal IP Rights remain vested in the companyborrower, which will continue to be responsible for the maintenance of the Formal IP Rights. 
- formalities for creating a pledge over the Formal IP Rights are comparable to the ones that are traditionally provided for the immovable assets (real properties) [9].

National specific features of legal regulation and registration of pledge in some EU countries are provided in Tab. 1.

TABLE I. CHARACTERISTICS OF PLEDGE REGISTRATION FOR OBTAINING CASH LOANS IN SELECTED EU COUNTRIES

\begin{tabular}{|c|c|c|c|}
\hline Country & Pledge object & Legal provisions & $\begin{array}{c}\text { Pledge } \\
\text { Registration } \\
\text { Authority }\end{array}$ \\
\hline Britain & $\begin{array}{l}\text { Patent or patent } \\
\text { application }\end{array}$ & $\begin{array}{l}\text { Section } 33 \text { of the } \\
\text { Patents Act } 1977\end{array}$ & $\begin{array}{l}\text { It is advised to } \\
\text { register the pledge } \\
\text { at the UK } \\
\text { Intellectual } \\
\text { Property Office. } \\
\text { The lack of the } \\
\text { pledge registration } \\
\text { at the UKIPO } \\
\text { would release a } \\
\text { subsequent patent } \\
\text { assignee, licensee } \\
\text { or pledgee from the } \\
\text { pledge, provided } \\
\text { they were unaware } \\
\text { of it }\end{array}$ \\
\hline Spain & $\begin{array}{l}\text { Trademarks and } \\
\text { patents as well } \\
\text { as their } \\
\text { registration } \\
\text { requests }\end{array}$ & $\begin{array}{l}\text { Spanish Patent } \\
\text { and Trademarks } \\
\text { Register (Article } \\
46 \text { of Law } \\
17 / 2001 \text {; Articles } \\
74 \text { and } 79 \text { of Law } \\
11 / 1986)\end{array}$ & $\begin{array}{l}\text { The security is } \\
\text { binding against } \\
\text { third parties of } \\
\text { good faith if it is } \\
\text { duly registered in } \\
\text { the Spanish Patent } \\
\text { and Trademarks } \\
\text { Register }\end{array}$ \\
\hline Italy & $\begin{array}{l}\text { Trademarks and } \\
\text { patents }\end{array}$ & $\begin{array}{l}\text { Articles } 138 \text { and } \\
140 \text { of the Italian } \\
\text { Code } \\
\text { Intellectual on } \\
\text { Property } \\
\text { (Legislative } \\
\text { Decree no. } \\
30 / 2005) 30 / 2005 \text { ) }\end{array}$ & $\begin{array}{l}\text { Pledge is effective } \\
\text { upon registration } \\
\text { with UIBM (Italian } \\
\text { Registrar for } \\
\text { Trademarks and } \\
\text { Patents) }\end{array}$ \\
\hline Hollan & $\begin{array}{l}\text { Rights to } \\
\text { databases, } \\
\text { industrial } \\
\text { designs, } \\
\text { patents, } \\
\text { trademarks and } \\
\text { trade names }\end{array}$ & $\begin{array}{l}\text { The Civil Code of } \\
\text { the Netherlands, } \\
\text { book } 3 \text { (articles 3: } \\
231(1), 3: 234,3: \\
246(4), 3: 248,3: \\
\begin{array}{l}249,3: 250,3: \\
252,3: 255,3: \\
68)\end{array}\end{array}$ & $\begin{array}{l}\text { Each IP pledge } \\
\text { agreement must be } \\
\text { registered with the } \\
\text { tax authorities of } \\
\text { the Netherlands in } \\
\text { order to create a } \\
\text { valid pledge right. } \\
\text { In addition, the } \\
\text { pledge agreement } \\
\text { must be registered } \\
\text { in the } \\
\text { corresponding } \\
\text { registry of the IP of } \\
\text { the Netherlands } \\
\text { (each registry has } \\
\text { its own } \\
\text { requirements for } \\
\text { registration) }\end{array}$ \\
\hline France & $\begin{array}{l}\text { Trademarks and } \\
\text { patents }\end{array}$ & $\begin{array}{l}\text { French Code of } \\
\text { Intellectual } \\
\text { Property; } \\
\text { French } \\
\text { Commercial } \\
\text { Code (Article L } \\
142-1 \quad \text { governs }\end{array}$ & $\begin{array}{l}\text { Pledge is effective } \\
\text { upon registration } \\
\text { with INPI (National } \\
\text { Institute for } \\
\text { Industrial Property) }\end{array}$ \\
\hline
\end{tabular}

\begin{tabular}{|l|l|l|l|}
\hline Country & Pledge object & Legal provisions & \multicolumn{1}{|c|}{$\begin{array}{c}\text { Pledge } \\
\text { Registration } \\
\text { Authority }\end{array}$} \\
\hline & & $\begin{array}{l}\text { IPO pledge; } \\
\text { following article } \\
\text { L 143-17, pledge } \\
\text { is effective upon } \\
\text { registration with } \\
\text { INPI }\end{array}$ & \\
\hline
\end{tabular}

In addition to the specifics of pledge registration, provided in Tab. 1, there are additional requirements for the registration in the UK. For example, when the pledger is a UK company, it is necessary for the pledge to be registered at Companies House within 21 days of its creation. Section 860(7) (i) of the Companies Act 2006 makes clear that a pledge over any intellectual property should be registered. The process of registering a pledge at Companies House involves submitting a prescribed form together with a certified copy of the pledge document to Companies House, which can be done on-line through the Companies House portal. Companies House registration costs are minimal, amounting to a registration fee of $£ 13$ for each registration. In the absence of registration with Companies House during the 21-day limit, the pledge is void and unenforceable with respect to the liquidator or administrator or any creditor of the pledger, which potentially leads to the immediate return of the pledge security. As regards pledgers outside the UK, or non-UK patents, local advice as to perfection requirements will generally need to be obtained [12].

In its turn, the practice of the Netherlands shows that registration of a pledge agreement in the relevant IP registry is not always necessary for the actual creation of IP rights pledge (this depends on the right to IP) [11].

In the UK, specialists identify two basic methods of creating financial pledge over patents under English law (Tab. 2).

TABLE II. CHARACTERISTICS OF EXISTING METHODS OF CREATING FINANCIAL PLEDGE OVER PATENTS IN THE UK

\begin{tabular}{|c|c|c|}
\hline Criteria & Pledge of Patents & $\begin{array}{c}\text { Equitable pledge } \\
\text { agreement }\end{array}$ \\
\hline $\begin{array}{l}\text { Organizational } \\
\text { characteristics } \\
\text { of pledge } \\
\text { relations }\end{array}$ & $\begin{array}{l}\text { There is a transfer of the } \\
\text { patent right to the pledgee, } \\
\text { provided that the rights of } \\
\text { the pledger for patents are } \\
\text { transferred to him back } \\
\text { after the loan is repaid. }\end{array}$ & $\begin{array}{l}\text { A valid and executable } \\
\text { agreement is concluded } \\
\text { between the pledger and the } \\
\text { pledgee, establishing an } \\
\text { intention to create a pledge } \\
\text { interest. No transfer of title } \\
\text { to the relevant patents is } \\
\text { required }\end{array}$ \\
\hline Advantages & $\begin{array}{l}\text { It is the safest variant for a } \\
\text { pledgee }\end{array}$ & $\begin{array}{l}\text { In practice, it is often more } \\
\text { convenient for both parties }\end{array}$ \\
\hline Disadvantages & $\begin{array}{l}\text { It is often considered too } \\
\text { cumbersome for lenders }\end{array}$ & $\begin{array}{l}\text { In certain jurisdictions, a } \\
\text { lender may still insist on the } \\
\text { transfer of patent rights } \\
\text { (patents are offered as } \\
\text { pledge) because the law of } \\
\text { the country in which the } \\
\text { patent is registered permits } \\
\text { the transfer of patent rights, } \\
\text { but does not recognise a } \\
\text { pledge agreement }\end{array}$ \\
\hline
\end{tabular}

In accordance with the pledge practice of Great Britain, the pledger will need to consider and estimate carefully the 
consequences of entering into the pledge agreement and to scrutinise its terms. The pledgee will have the right to sell the patents in the event of a default by the pledger. If the pledgee has taken pledge over not just the patents but also the other business assets, the pledgee may have other options too, such as the power to appoint an administrator with authority to run the business of the defaulting pledger. The pledgee will wish to ensure that the value of the pledged patents is maintained; in the agreement, the pledgee may seek to impose obligations on the pledger to comply with such guarantee. The pledger would be well advised to seek to reserve the right either to allow a patent to lapse or to abandon a patent or a patent application which is reasonably considered to be no longer of value [11]. In this regard, there must be a guarantee that any security document does not prohibit him from doing it freely in any way.

In most cases the pledger will want the freedom to continue to exploit the patent portfolio as part of its business. In this regard, there must be a guarantee that any pledge document does not prohibit the pledger from doing it freely in any way. It should be emphasized that there is normally a community of interest between the pledger and pledgee in this context because the pledgee wants the business to generate revenue to repay the debt. The pledger has to negotiate the terms with the pledgee at the outset so as to make clear that any future licensee's interest is not at risk of being defeated by the pledgee, exercising its right to sell the patents in the event of default on the loan. In such cases, the pledger could offer as a compensation to the pledgee an access to the revenue generated by the licence either by agreeing to pay it directly to the pledgee or by giving the pledgee a pledge over the revenue stream itself [11].

The following principles of the EU, regarding pledging intellectual property rights, are mentioned. The Community Trade Marks (CTMs) system coexists with domestic systems. The CTM system is valid and enforceable across the European Union as a whole territory (and any new Member State).

Registration of trademarks with the Office for Harmonization in the Internal Market based in Alicante, Spain (OHIM) allows lenders/advisors to deal with:

a single Administrative Centre to be checked; a single filing procedure to be carried on; a priority regime valid in all the Member States.

The effects of CTMS are governed by the provisions of EC Council Regulation No. 207/2009 (2009 EC Regulation). Article 19 of the 2009 EC Regulation expressly provides for pledge over CTMs:

- CTMs may, independently of the undertaking, be given as a pledge or be the subject of rights in rem;

- Upon request of one of the parties, pledged CTMs or rights in rem shall be entered in the Register of Community Trademarks (Register) and published in the Community Trade Marks Bulletin (Bulletin).

The European Patent System provides for the procedure for granting the European Patent (EP). This procedure is administered by the European Patent Office (EPO) with the head office in Munich (Germany), which operates on the basis of international rules established in Munich in 1973 (European Patent Convention; latest update in 2010, 14th edition) (Munich EP Convention). Under the EP regime, EPs may be granted as pledge (see Article 71 of the European Patent Convention) and the relevant pledge needs to be filed with the EPO. National laws are applied in relation to the effect and validity of the pledges, including rules regarding the rights of a third party at the local level (see Articles 74 of the European Patent Convention) [9].

In Russia, the experience of IP pledge transactions is not big. This version of bank lending in the country began to be used only in 2009 and is at the initial stage of development (Tab. 3). The conclusion of any contracts (including pledge agreements) related to the disposal of an exclusive right to patented objects of intellectual property and trademarks in Russia is subject to registration in Rospatent [11].

TABLE III. NUMBER OF IPO PLEDGE AGREEMENTS REGISTERED BY ROSPATENT IN 2009-2016 [13]

\begin{tabular}{|l|c|c|c|c|c|c|c|c|}
\hline & $\mathbf{2 0 0 9}$ & $\mathbf{2 0 1 0}$ & $\mathbf{2 0 1 1}$ & $\mathbf{2 0 1 2}$ & $\mathbf{2 0 1 3}$ & $\mathbf{2 0 1 4}$ & $\mathbf{2 0 1 5}$ & $\mathbf{2 0 1 6}$ \\
\hline $\begin{array}{l}\text { Pledge } \\
\text { agreements } \\
\text { over } \\
\text { exclusive } \\
\text { rights to } \\
\text { the results } \\
\text { of } \\
\text { intellectual } \\
\text { activity }\end{array}$ & - & 8 & 16 & 17 & 20 & 15 & 13 & 9 \\
\hline $\begin{array}{l}\text { Pledge } \\
\text { agreements } \\
\text { over } \\
\text { exclusive } \\
\text { rights to } \\
\text { trademarks }\end{array}$ & 16 & 62 & 52 & 24 & 60 & 40 & 58 & 72 \\
\hline $\begin{array}{l}\text { Number of } \\
\text { trademarks } \\
\text { referring to } \\
\text { which the } \\
\text { pledge } \\
\text { agreements } \\
\text { are } \\
\text { concluded }\end{array}$ & N/A & 195 & 280 & 82 & 191 & 258 & 362 & 689 \\
\hline $\begin{array}{l}\text { Total } \\
\text { number of } \\
\text { pledge } \\
\text { agreements } \\
\text { over } \\
\text { exclusive } \\
\text { rights to } \\
\text { IPOs }\end{array}$ & 16 & 70 & 68 & 41 & 80 & 55 & 71 & 81 \\
\hline
\end{tabular}

The main constraint on the issue of extending the practice of bank lending against IP's pledge is the difficulty in assessing the value of pledged assets as intangible assets [14; 15]. From the authors' point of view, the existing Russian experience with the use of IP's as a pledge for obtaining credit and applying the experience of European countries today can serve as a solid foundation for activating lending in the banking services market; and the pledge over IP rights can be a promising tool for the development of companies actively

Thus, the pledge over intellectual property rights is an opportunity to build a close and, most importantly, mutually 
beneficial interaction between science and business, which are the two participants in the Quadruple-Helix Model of building national and regional innovation systems. The third party is government. The mechanism for pledging intellectual property rights is used as the starting point for innovative development of the economy. At the same time, the role of government is to ensure, including the legislative provision, the security of pledge transactions. Government that acts as a guarantor in an IPO pledge transaction reduces the risks of the pledgee significantly, thereby increasing the attractiveness of such transactions.

Government influences pledge relations through economic and administrative methods which are based on the guarantee mechanism. The basis of legal regulation of pledge relations is the government guarantees of pledgee's rights which are called upon to provide an adequate protection in case of owners' interests violation while carrying out innovative activities. Wherein, government, as a rule, guarantees first of all the stability of rights, which is very important in long-term relations.

In order to define the meaning of "government guarantee mechanism of pledging intellectual property objects" concept, it must be borne in mind that these are a form of social guarantees. These mean material and legal means that ensure the realization of the social and economic rights of society members. Consequently, legal guarantees of investment are legal means ensuring the implementation of the rights of the parties.

In the legal sense, the concept of "guarantee" is defined as a system for ensuring the reality of rights established by law. This system includes ensuring the monitoring of compliance with the legislation, the activities of relevant government authorities, as well as legislative norms that ensure the stability of public relations.

Thus, the essence of guarantees provided by national legislation is to not violate the rights of the interacting parties and ensure their implementation. The peculiarity of these guarantees lies in the fact that they come from government itself. Government assumes the obligation to perform certain actions in relation to the pledger or refrain from actions that violate its rights and legitimate interests.

The essence of the guarantee mechanism is the specific obligations of the government to ensure the security of the pledgee's property. Analyzing the state of Russia's notion of "government guarantees as the basis for ensuring a secure IPO pledge", the following should be highlighted: IPO is a specific object, with a complex estimation of its value and, therefore, very risky.

For full-fledged government involvement as a guarantor, when conducting IPO pledge transactions between science and business, it is necessary:

- to expand the pledge law on the basis of the world's leading practices, international agreements on the forms and methods of protecting the rights of participants in IPO pledge transactions;
- to define clearly, preferably legally, the ultimate goal of government actions in this area, which is ensuring the security of participants' property in IPO pledge transactions and the actual realization of their rights as well.

After implementing the above measures, it is possible to get a clear and transparent model of interaction between science, business and government (authorities) in creating innovative growth points based on the mechanism of IPO rights pledging.

Within the innovation process, it is necessary that the relationships between government, business and society are balanced. The imbalance of these relationships leads to the inefficiency of the innovation process. In the conditions of totalitarianism, it is difficult to carry out innovative activities because government dictates to the business what and in what volumes to produce, therefore the enterprises do not have the opportunity to realize the ideas of new products. Anarchy also does not promote innovation, because in the conditions of anarchy it is generally difficult to carry out production. In the situation of the "economy of individuals" it is also difficult to innovate. This is because the managers of enterprises are not aimed at the prosperity of the enterprises they work for. Their personal benefit is more important for them. They will be more willing to steal the enterprise's property than improving the production process, especially, creating new products.

It should be understood that such instrument as a pledge of IP does not only depend on patent activity as the more patents are registered, the higher the probability of obtaining a loan on the pledge of IP. On the other hand, the development of this instrument spurs the patient activity. With an increased probability of obtaining loan funds secured by IP, market participants "are tempted" to patent technical solutions, which cannot be done without conducting high-quality high-tech research.

In the course of the study conducted by the authors it has been established that not all banks in Russia, participating in IP pledge agreements, have a regular nature of concluding such transactions. All the banks, participating in pledge agreements registered in the period from 2013 to 2016 in Rospatent, can be divided into the three categories:

- banks that regularly participate in collateral transactions (for example, Sberbank of Russia, PJSC, Moscow Credit Bank, OJSC, International Financial Club (IFC Bank), JSC JSCB and other banks that are registered as pledgees in repeated annual pledge transactions);

- banks that periodically participate in collateral transactions (for example, Far Eastern Bank, OJSC participated once in the pledge agreements in 2013 and 2014; Financial Corporation Discovery Bank, PJSC in 2013, 2015 and 2016; Promsvyazbank, OJSC - in 2013 and as Promsvyazbank, PJSC - in 2016; Russian Agricultural Bank, OJSC - in 2013 and 2016, etc.);

- banks - one-time participants in collateral transactions (for example, the European Bank for Reconstruction 
and Development in Great Britain, Center-Invest Commercial Bank, OJSC, Joint Stock Commercial Bank Absolut Bank, Investment Bank VESTA, LLC, Amsterdam Trade Bank in the Netherlands and other banks). (Tab. 4).

TABLE IV. THE NUMBER OF REGISTERED CONTRACTS OF PLEDGE

\begin{tabular}{|c|c|c|c|c|c|}
\hline \multirow{2}{*}{ The bank } & \multicolumn{5}{|c|}{ The number of registered contracts of pledge } \\
\hline & 2013 & 2014 & 2015 & 2016 & Total 2013-2016 \\
\hline Sberbank & 3 & 14 & 20 & 9 & 46 \\
\hline $\begin{array}{l}\text { Credit Bank of } \\
\text { Moscow }\end{array}$ & 2 & 3 & 4 & 1 & 10 \\
\hline Otkritie Bank & 2 & 0 & 3 & 2 & 7 \\
\hline $\begin{array}{l}\text { United financial } \\
\text { capital Bank }\end{array}$ & 0 & 0 & 2 & 5 & 7 \\
\hline $\begin{array}{l}\text { International } \\
\text { Financial Club } \\
\text { (IFC Bank) }\end{array}$ & 1 & 2 & 1 & 2 & 6 \\
\hline $\begin{array}{l}\text { Russian } \\
\text { Agricultural Bank }\end{array}$ & 1 & 0 & 0 & 4 & 5 \\
\hline Probusinessbank & 5 & 0 & 0 & 0 & 5 \\
\hline Nefteprombank & 2 & 1 & 1 & 0 & 4 \\
\hline MDM Bank & 2 & 0 & 2 & 0 & 4 \\
\hline RUSSITABANK & 0 & 3 & 0 & 1 & 4 \\
\hline $\begin{array}{ll}\text { Bank } & \text { Saint } \\
\text { Petersburg } & \end{array}$ & 0 & 1 & 2 & 0 & 3 \\
\hline UniCredit Bank & 1 & 1 & 0 & 1 & 3 \\
\hline $\begin{array}{l}\text { BANK } \\
\text { URALSIB }\end{array}$ & 0 & 0 & 1 & 2 & 3 \\
\hline BM-Bank & 0 & 1 & 0 & 1 & 2 \\
\hline Promsvyazbank & 1 & 0 & 0 & 1 & 2 \\
\hline
\end{tabular}

The authors of the given article have built a rating of banks on the total number of registered pledge agreements for IP over the analyzed period from 2013 to 2016. At the same time, all the banks participating in the IP pledge agreements are divided into 3 groups (without taking into account the periodicity of the conclusion of contracts):

- the most active banks; participated in 5 or more registered IP collateral agreements over the analyzed period of time;

- active banks; participated in two or four registered IP collateral agreements over the analyzed period of time;

- least active banks; participated in one IP collateral agreement, registered with Rospatent, over the analyzed period of time.

The mentioned banks-participants of pledge agreements as pledgees of IP were found in the rating of Russian banks at the cost of their brands. From this rating it can be seen that the majority of the most active banks that participated in collateral transactions with IP are included in the first "twenty" in the rating of Russian banks by this criterion. This indicates that these banks are concerned about the value of their brands and are working on the issue of promoting their service marks on the market.
In the rating of Russian banks on the loan portfolio (as of May 2017), the most active participating banks of collateral agreements as pledgees of IP appear in the first hundred banks out of a total of 582 Russian banks.

\section{CONCLUSION}

Summarising the discussion above the following can be stated. Holding IP pledge transactions accelerates the pace of creating innovative systems in the economy. The main constraint on the issue of extending the practice of bank lending against pledge for IP rights is the difficulty in estimating the value of pledged assets as intangible assets. In the applied perspective, the analysis of the current patent information allows tracking trends in markets created by hightech goods and services, determining the feasibility of exporting industrial products, searching for industrial partners, etc.

\section{References}

[1] Patent Cooperation Treaty Yearly Review. June 2015. http://www.wipo.int/edocs/pubdocs/en/wipo_pub_901_2015.pdf.

[2] World Intellectual Property Indicators. June 2015. http://www.wipo.int/edocs/pubdocs/en/wipo_pub_941_2015.pdf.

[3] S.M. Nikitenko, E.V. Goosen, V.I. Klishin, "Experience of interaction of institutions of academic science with business on the principles of PPP (on the example of the Institute of Coal, SB RAS, Kemerovo)", Innovations, vol. 9 (179), pp. 9-19, 2013.

[4] E.V. Goosen, "Prospects for the development of PPP projects in the Fuel and Energy Complex of Russia: assessment and current state", Fundamental research, vol. 11-2, pp. 362-366, 2016.

[5] A.V. Khotinskaya, "Intangible assets as marketing resource of the company", Service plus, vol. 3, pp. 54-58, 2007.

[6] Anatomy of Growth. Top Growing Brands. 2016. - Available at: http://interbrand.com/best-brands/best-global-brands/2016/

[7] Code de la propriété intellectuelle (version consolidée au 23 février 2015). - $\quad$ Available at: http://www.wipo.int/wipolex/en/text.jsp?file_id=363403 (accessed: 29.01.2017).

[8] Dutch Civil Code, Book 3. - Available at: http://www.dutchcivillaw.com (accessed: 08.02.2017).

[9] Livio Esposizione. IP rights and loan financing: European perspective. Available at: http://techlaw.org/wp-content/uploads/2011/05/110426_IPrights-and-loan-financing_1.pdf?x13654 (accessed: 29.01.2017).

[10] Contributing editor George E. Zobitz Cravath, Swaine \& Moore LLP, Loans \& Secured Financing 2016, London: Law Business Research Ltd, 2016, 120 p.

[11] J. Marshall, R. Caldwell, B. Cain, Taking security over patents. Available at: https://unitedkingdom.taylorwessing.com/synapse/march14.html (accessed: 29.01.2017).

[12] O. Ruzakova, Exclusive rights pledge agreement. - Available at: http://superpressa.ru/index.php?Itemid=82\&id=105\&option=com_conte nt\&task=view (accessed: 20.02.2017).

[13] Report on the Rospatent activities in 2016. - Available at: http://www.rupto.ru/about/reports/2016/otchet_2016_ru.pdf (accessed: 08.04.2017).

[14] E.S Kagan, E.V. Goosen, "Resource regions: qualitative and quantitative criteria of allocation", Scientific Technologies For Development And Use Of Mineral Resources, vol. 3, pp. 163-170, 2017.

[15] S. M. Nikitenko, E. V. Goosen, K. S. Sablin "Perspectives of the Comprehensive Mineral Exploitation Based on the Principles of the Public-Private Partnership", IOP Conference Series: Earth and Environmental Science, 2016 [International Scientific and Research 
